\title{
Does Islamic Banking Augment Banking Sector Development in Pakistan?
}

\author{
Muhammad Hanif Akhtar, Naariah Hanif \\ Bahauddin Zakariya University, Multan, Pakistan
}

\begin{abstract}
Given the remarkable growth of Shariah-based banking in Pakistan and worldwide, the question does arise if Islamic banks contribute in the overall development of banking. The paper is an attempt to discover the role of Islamic banks towards the banking sector development in Pakistan. The study covers a period of 12 years (2006-2017) where the impact of Islamic banks in overall development of banking sector, is estimated by using deposits by Islamic banks as a percent of GDP. Deposits are an important parameter here since these reflect the resource mobilization by Islamic banks and their ability to marshal the deposits into activities that generate revenue for them. The study also makes use of variables e.g. financial sector's development, growth of GDP and inflation. The role of Islamic banks towards the overall banking development is also estimated through penetration propensity of Islamic banks over the period of analysis. A regression analysis has been used to estimate the impact of the dependent variable across the explanatory ones. The research offers some managerial as well as policy implications along with an agenda for future research.
\end{abstract}

Keywords: Islamic Banks, Banking Sector, Panel Data, Financial Sector Development, Pakistan

\section{Introduction}

Growth of Shariah-compliant banking has occurred at a phenomenal speed globally, over the last few decades, Pakistan being no exception. A number of factors seem to be working behind this growth trajectory. Firstly, the assetbased and asset-backed nature of the Islamic banking system provides it a resilience to deal with speculative shocks in the market; the financial crisis of 2007-08 can be quoted as an example. Secondly, there has been a growing awareness of the use of Shariah-compliant banking services among the Muslim

Corresponding Author: Hanif Akhtar, e-mail: haneefakhtar@bzu.edu.pk

- COMSATS University Islamabad, Lahore Campus, Pakistan 
community globally. Thirdly, there appears to be an increasing tendency among Muslim countries to switch gradually towards Islamic banking over the course of time in future. Last but not the least, growing interest in Islamic banking is also taking place due to an increasing demand for non-conventional finance towards meeting the sustainable development goals (Cham, 2018). For such reasons, Shariah banking has moved from a niche market into the mainstream (Imam \& Kpodar, 2013).

Banking sector has been considered as the alpha and omega of all the business transactions and economic growth through mobilization of resources. By the same notion, Islamic banks has an important role in overall expansion of banking and growth of an economy in many ways. First Islamic banking might increase the volume of deposits through the process of financial inclusion of those clients who tend to prefer Islamic banking over the conventional one on religious grounds. Secondly, Islamic banks bear the potential to introduce financial innovation through Shariah-compliant financial products which might enhance participation in the banking system. The financial innovation by Islamic banks might also generate spillover effects by pushing their conventional counterparts to expand their product offerings to remain competitive in the financial markets (Gheeraert, 2014). Finally, the growing nature of Islamic banking segment through the creation of newer Islamic banks might also impact the banking industry both positively and negatively. The potential negative impacts might take the form of higher market concentration by Islamic banks while the positive impacts might result into higher degree of market competition with an increased number of players. Given these reasons, the growth of Islamic banking is expected to result in greater levels of both deposits and credit in an economy which can lead towards the overall banking sector development.

The authors could not find the existence of an empirical work in terms of Shariah compliant banking towards development of the overall banking sector in Pakistan (The claim is based on the fact as only two of the studies could be traced in context of impact of Islamic banks on economic growth of Pakistan by Rafay and Farid (2017) and Kalim et al. (2016). Thus, the present research is an attempt to fill this gap.

Quite a few studies could be found to assess the overall contribution of Islamic banking towards the development of the banking system across the globe. The study by Lone and Ahmad (2017) discovered that Islamic banks make valuable contributions towards improvement in the banking area while serving the society well. Their findings are supported by Imam and Kpodar (2016) as in their view, Islamic banking complements conventional banks.

Rafay and Farid (2017) investigated the existence of a long-term relation 
between Islamic banks and real economic activity in Pakistan. Their findings revealed the existence of a two-way relationship between growth of Islamic banking and the activity of real economy. This means growth in Islamic banking strengthens the real economic activity while an improvement in the latter also supports the former in the country. Using the techniques like Impulse Response Functions (IRF) and Variance Decomposition Analysis (VDA), they discovered that an increase in deposits by Islamic banks improves the real economic activity and the same is reinforced by the VDA analysis. However, the effect of Islamic banking was not so significant in short run compared to the long run period. This might be due to a lesser stake of the Islamic banks in the overall banking industry of Pakistan.

Kalim et al. (2016) tested the impact of various Islamic products across growth of Pakistan for the period of 2006-2013, They advocate the existence of a long run association across Islamic finance products like net financing, Ijarah and economic growth of a country like Pakistan. They further discovered that activities like net financing, gross fixed capital formation, Ijarah and diminishing Musharikah by Islamic banks granger cause economic growth.

Gheeraert (2014) studied the influence of Islamic banks across the banking sector growth during 2000 to 2005 . He established that Islamic banking development in Islamic countries escorts to a greater banking progress as assessed by private credit and deposits to GDP ratios. His results revealed that Islamic banks act as a complement to their non-Islamic counterparts in Islamic countries.

Beck et al. (2013) investigated a large sample of banks from 141 countries of the world during the period of 1995-2007 which also included 99 Shariah-compliant banks. They asserted that both Islamic and non-Islamic banks had a small difference in their business model, efficiency, asset quality and stability. They also discovered Islamic banks significantly impacting conventional banks while a greater share of Islamic banking increases cost efficiency and decreases the stability of non-Islamic banks. Their study confirms the hypothesis that Islamic banking growth would strengthen the banking competition and is therefore, supportive to the overall banking sector. However, for some researchers, Islamic banking system can raise social and economic development while the religiousminded people avoid the use of conventional banking since Shariah-compliance provides them mental peace and relaxation since they do not disobey the commandments of Allah Almighty. (Kumru \& Sarntisart, 2016).

Rest of the discussion goes as follows: Section 2 presents some conventional facts on Islamic banks in Pakistan. Section 3 is devoted to methodology which specifies the empirical model while the findings are discussed in section 4 of the study. Section 5 concludes with policy implications and the future research agenda. 


\subsection{Few conventional facts on Pakistani Islamic Banks}

Islamic banking is based on doctrines of Islamic Shariah and its activities are regulated by Islamic principles. This is largely driven by the prohibition of riba (interest), maysir (gambling), gharar (speculation) and businesses that are haram e.g. producing or trading in pork, alcohol, or any form of businesses that is considered illegal in Islam. The drive towards Islamization of banking system started in the late 70 s and early 80 s in Pakistan and since July 1, 1985, banking was made interest-free. In the year 2001, State Bank of Pakistan (SBP) came up with the first Islamic banking policy and the first Islamic banking license was issued to offer a complete range of Islamic products in the year 2002. The traditional banks have also been given licenses to offer Islamic banking services through Islamic windows or branches.

The SBP has also crafted a Shariah compliant mechanism which ensures that Islamic banks are adhering to Shariah principles while developing and selling the financial products. Three major pillars of the policy consist of Shariah board, Shariah advisors and Shariah audit system. These pillars respectively approve all the policies; provide guidelines and evaluate institution's performance on a regular basis. Islamic banks are offering a variety of products which are taking the form of Diminishing Musharikah (partnership by mutual contract), Murabaha (cost plus profit sale), Ijarah (lease activity), Musawamah (bargain sale), Istisna' (sale on order), Bai Muajjal (credit sale), Mudarabah (trustee profit sharing), Musharikah (joint venture profit sharing) and Salam (commodity sale) etc.

It would be pertinent to mention here that Pakistan stands among pioneer countries of the world to introduce Islamic banks which have grown in assets, deposits and profits overtime. Assets of Islamic bank industry grew by Rs. 148 billion and stood at Rs. 2,482 billion during the period of April to June 2018 (SBP, 2018). Likewise, deposits of Islamic banks also increased by Rs. 117 billion during the same period reaching Rs. 2,033 billion by the end of June 2018. In the overall banking industry, the market share of assets and deposits by Islamic banks reached to 12.9 percent and 14.8 percent respectively by the end of June 2018 . On profitability front, the profit of Islamic banks reached to the level of Rs. 15 billion by the end of June 2018 compared to Rs. 12 billion in the same quarter of 2017 (SBP, 2018).

\section{Methodology}

\subsection{Data and Variables}

The Present research uses a panel data for 4 Islamic banks (Out of the total population of 5 local banks in Pakistan, 4 for selected for the analysis based 
on the consistent availability of the data.) in Pakistan for the period of 2006 to 2017. The data was extracted from the Annual Banking Statistics, a publication of the State Bank of Pakistan and the World development indicators (WDI) of the World Bank. The banking sector progress is proxied by the ratio of credit to GDP (Credit/GDPAB) which serves as the dependent variable. The independent variables include deposits to GDP ratio for Islamic banks (Deposits/GDPIBs), level of financial development (FD) in Pakistan represented by M2 as a percent of GDP, growth of GDP (GDPG) and inflation (INF). The choice of independent variables has been determined through the extant literature and in context of the banking system in Pakistan. A complete description, of the variables used, is provided in table-1 as below:

Table-1: Description of variables used with their expected signs

\begin{tabular}{|c|c|c|}
\hline Variables & Measurement & $\begin{array}{l}\text { Expected } \\
\text { signs }\end{array}$ \\
\hline $\begin{array}{l}\text { Dependent variable } \\
\text { Banking sector } \\
\text { development } \\
\left(\text { Credit/GDP } P_{A B}\right)\end{array}$ & $\begin{array}{l}\text { Measured as the ratio of private credit (Credit) by all } \\
\text { the banks to GDP. }\end{array}$ & \\
\hline \multicolumn{3}{|l|}{ Independent variables } \\
\hline Deposits (Dep/GDP) & Measured as the ratio of deposits to GDP. & +ive \\
\hline $\begin{array}{l}\text { Banking penetration } \\
\text { (Credit } \times \text { Deposits) }\end{array}$ & The interaction term measured by Credit $\times$ Deposits. & +ive \\
\hline $\begin{array}{l}\text { Financial development } \\
\text { (FD) }\end{array}$ & Measured as the ratio of $\mathrm{M}_{2}$ to GDP. & +ive \\
\hline GDP Growth (GDPG) & Measured as growth rate of GDP. & +ive \\
\hline Inflation (INF) & Measured by the GDP deflator in Pakistan. & -ive \\
\hline
\end{tabular}

\subsection{Model Specification}

To capture the role of Islamic banks in development of the banking sector in the country, the following model is specified.

$$
\frac{\text { Credit }}{G D P_{i}}=\alpha+\beta_{1} \frac{D e p}{G D P}(I B s)_{i}+\beta_{2}(C r \times D e p)_{I B S}+\beta_{3} X_{i}+\varepsilon_{i}
$$

Here, $X_{i}$ represents a vector of control variables which include financial development, GDP growth and inflation while $\varepsilon$ is the error term.

\section{Discussion of Results}

To test for the influence of Islamic banks on the development of the banking sector, both bank-specific and macroeconomic variables have been considered as presented in table-1 above. Likewise, to control for the economic development and business cycle effects, country-specific considerations have been placed, too. Before conducting the panel data regression analysis, descriptive statistics of variables are examined as under: 


\subsection{Descriptive statistics}

Descriptive statistics are the coefficients that outline a specified data set, that can either be a description of the entire population or a sample of it. Descriptive statistics are divided into measures of dispersion and central tendency. Measures of dispersion represent the standard deviation, maximum and minimum while measures of central tendency include the mode, mean and median. Before conducting the intended analysis, descriptive statistics are checked to test for the normalization of data. These are presented in table-2 below displaying mean, standard deviation along with the maximum and minimum for each of the variables used in the study.

Table 2: Descriptive Statistics

\begin{tabular}{|c|c|c|c|c|c|c|}
\hline & Credit & Deposits & $\mathbf{C r} \times$ Dep & Inflation & $\mathbf{M}_{2}$ & GDPG \\
\hline Mean & 278.327 & 497.194 & 4.732 & 9.962 & 53.765 & 4.036 \\
\hline SD & 263.548 & 488.886 & 1.055 & 6.537 & 3.009 & 1.487 \\
\hline Min & 0.4005 & 0 & 0 & 0.400 & 48.1 & 1.607 \\
\hline Max & 1341.36 & 2106.15 & 6.451 & 20.667 & 58.868 & 6.178 \\
\hline
\end{tabular}

Table 3: Islamic banking effect on overall banking development

\begin{tabular}{|c|c|c|c|c|c|}
\hline Variable & Coefficients & Std. Error & t-Statistics & Sig & VIF \\
\hline Constant & -774.230 & 228.577 & -3.387 & .002 & --- \\
\hline Deposits & .475 & .026 & 18.242 & .000 & 2.311 \\
\hline Log_Cr $\times$ Dep & 32.671 & 13.666 & 2.391 & .021 & 2.968 \\
\hline $\mathrm{M}_{2}$ & 11.188 & 3.761 & 2.975 & .005 & 1.829 \\
\hline Inflation & 1.930 & 1.780 & 1.084 & .284 & 1.934 \\
\hline GDPG & 10.187 & 7.437 & 1.370 & .178 & 1.746 \\
\hline
\end{tabular}

Islamic banking supports the process of overall banking development as divulged by the regression results in table-3 above. Coefficients like deposit/GDP ratio and the Islamic banking penetration, reinforce each other to confirm the contribution of Islamic banks towards the banking sector development in Pakistan. The variables are significantly positive, while the findings are consistent with those by Lone and Ahmad (2017), Gheeraert (2014) and Beck et al. (2013). These results further carry the message that Islamic banking in Pakistan might have reached at a certain critical mass to impact the overall banking system of the country. The supply of funds by Islamic banking channels might be leading to positive externalities both for the banks as well as the economy. 
Financial development can affect the overall banking system and has been considered as conducive to economic growth while the standard of overall financial development is very important (Imam \& Kpodar, 2015). The level of financial development is positive and significantly associated with banking sector development in Pakistan. This is as per expectations since banks serve as an important conduit of monetary policy transmission mechanism. In this milieu, our findings are consistent with those by Imam \& Kpodar (2016) and (Kalim et al. 2016).

The variables like inflation and GDP growth have emerged as insignificant in our analysis. Nevertheless, evidence on the effects of inflation and GDP growth towards the banking sector's performance remains murky (Bikker \& Hu, 2002 and Tan \& Floros, 2012).

\section{Conclusions}

Given the growth trajectory of Shariah-based banking in Pakistan, it is pertinent for policy makers to discover the effects of Islamic banking across the overall banking development in the country. A reconfirmation on this front also helps to support the increasing popularity of Shariah-compliant products by Islamic banks. The study is the first of its kind to address this issue on empirical grounds in Pakistan. Given the fact that both Islamic and non-Islamic banks are in competition with each other yet, the existence of Islamic banks provides an acceptable solution to the religious-minded people in the country.

Results of the panel data regression reveal that Shariah-based banking supports the development of the banking sector. Coefficients on deposit/GDP ratio and Islamic banking penetration reinforce each other to confirm the augmentation of banking in Pakistan by the Islamic banks.

The study also offers some useful policy and managerial implications for policy makers and managers of Islamic banks in Pakistan. On policy front, it can be recommended that the share of Islamic banks needs to be augmented further and those who are financially excluded might be encouraged to make use of Islamic banking products. In terms of managerial considerations, it would be useful for managers of these banks to maintain and intensify resource mobilization drive through deposit generation and credit creation.

The study owns certain limitations in terms of a single country analysis and lacks generalization of results. However, it supports the findings made in a multicountry study by Gheeraert (2014). Given that the Islamic banking has reached its critical mass, a natural extension of the study might be to examine whether 
Islamic banking serves as a substitute for or a complement to non-Islamic banks in a Muslim majority country like Pakistan. However, this can be an agenda for the future.

\section{References}

Bikker, J. and Hu, H. (2002), "Cyclical patterns in profits, provisioning and lending of banks and procyclicality of the new Basel capital requirements", BNL Quarterly Review, Vol. 221, pp. 143-75.

Cham, T. (2018). Determinants of Islamic Banking Growth: An Empirical Analysis. International Journal of Islamic and Middle Eastern Finance and Management, 11(1), 18-39.

Fayaz Ahmad Lone, and Siraj Ahmad (2017) Islamic finance: more expectations and less disappointment, Investment Management and Financial Innovations, Volume 14, (1), pp: 134-141.

Gheeraert, L. (2014). Does Islamic finance spur banking sector development? Journal of Economic Behavior and Organization. Vol. 103, pp: 1-17.

Gheeraert, L., \& Weill, L. (2015). Does Islamic banking development favor macroeconomic efficiency? Evidence on the Islamic finance-growth nexus, Economic Modelling, 47(2012), 32-39.

Imam, P., \& Kpodar, K. (2013), Islamic banking: how has it expanded? Emerging Markets Finance and Trade, 49(6), pp. 112-137.

Imam, P., \& Kpodar, K. (2016). Islamic banking: Good for growth? Economic Modelling, 59,387-401.

Kumru, C. S., \& Sarntisart, S. (2016). Banking for those unwilling to bank: Implications of Islamic banking systems. Economic Modelling, 54, 1-12.

Rafay Abdul and Saqib Farid (2017) Dynamic Relationship between Islamic Banking System and Real Economic Activity: Evidence from Pakistan, JKAU: Islamic Econ., Vol. 30 No. 2, pp: 97-116.

Rukhsana Kalim, Afia Mushtaq and Noman Arshed, (2016) Islamic Banking and Economic Growth: Case of Pakistan, Islamic Banking and Finance Review, 3 (1), pp:14-28.

State Bank of Pakistan (2018) Islamic Banking Bulletin, Karachi: SBP.

State Bank of Pakistan (2017) Banking Statistics of Pakistan, Karachi: SBP. 
Yong Tan \& Christos Floros (2012) Bank profitability and GDP growth in China: a note, Journal of Chinese Economic and Business Studies, 10:3, 267273.

Yong Tan (2016) The impact of risk on bank profitability in China, Journal of International Financial Markets, Institutions and Money, 40, PP: 85-110.

World Bank (2018) World Development Indicators, Database. 